\title{
On-Farm Diversity and Genetic Erosion of Tetraploid Wheat Landraces in Ambo and Dandi Districts, West Shewa, Ethiopia
}

\author{
Negash Geleta $^{1^{*}}$ and Heinrich Grausgruber ${ }^{2}$ \\ ${ }^{1}$ Wollega University, College of Agriculture and Natural Resources, Department of Plant Sciences, \\ Nekemte, Ethiopia \\ ${ }^{2}$ BOKU- University of Natural Resources and Applied Life Sciences, Department of Applied \\ Plant Sciences and Plant Biotechnology, Institute of Agronomy and Plant Breeding, \\ Vienna, Austria, A-1180
}

\begin{tabular}{|c|c|}
\hline Abstract & \\
\hline $\begin{array}{l}\text { The aim of the study was to document wheat landraces that were and still grown in Ambo } \\
\text { and Dandi districts, West Shewa, Ethiopia; and to investigate the extent of genetic loss } \\
\text { and its causes. Survey was carried out in three Peasant Associations of Ambo District and } \\
\text { four Peasant Associations of Dandi District from } 2007 \text { to } 2008 \text {. Three to five farmers' group } \\
\text { per Peasant Association containing } 5 \text { to } 12 \text { individual farmers per group were used for } \\
\text { group discussions from September to December, 2007; and a survey in } 90 \text { households } \\
\text { was conducted using semi-structured questionnaire prepared by researcher from August } \\
\text { to October } 2008 \text {. In total } 20 \text { diverse tetraploid wheat landraces were identified in the study } \\
\text { areas. However, presently } 4 \text { to } 5 \text { landraces are cultivated. Genetic erosion was } 75 \% \text { and } \\
62 \% \text { in Ambo and Dandi district, respectively. The landraces differ concerning morphology, } \\
\text { adaptation and end-uses. Some landraces exhibit broad adaptation that enables them to } \\
\text { be cultivated in a wider area over different districts. Specific adaptation to various soil } \\
\text { conditions, e.g. water logging and poor soil fertility, and short rainy season play key roles } \\
\text { for the predominant cultivation of specific landraces over others in sensitive environments. } \\
\text { Preferences for end-use products and market prices also display major impacts on the } \\
\text { continuous cultivation of tetraploid wheat. The causes for the loss of landraces varieties } \\
\text { were expansion of improved bread wheat varieties, low soil fertility and poor yield of the } \\
\text { landraces, and shorter rainy season. Among the available varieties, kamadi-Dima, is } \\
\text { predominantly grown in both districts, due to its higher price in the market for its brewing } \\
\text { quality. Diverse farmers' indigenous knowledge supported continued cultivation and } \\
\text { conservation of landrace varieties. }\end{array}$ & $\begin{array}{l}\text { Article History: } \\
\text { Received : 02-01-2013 } \\
\text { Revised : 18-03-2013 } \\
\text { Accepted : 19-03-2013 } \\
\text { Keywords: } \\
\text { Diversity } \\
\text { Genetic Erosion } \\
\text { Landraces } \\
\text { Tetraploid Wheat } \\
{ }^{*} \text { Corresponding Author: }\end{array}$ \\
\hline
\end{tabular}

\section{INTRODUCTION}

Ethiopian wheat includes tetraploid and hexaploid species. Tetraploid wheats are indigenous, whereas hexaploid wheats are probably a recent introduction (Bechere et al., 2000). The central Ethiopian highlands are the major durum producing region. The crop is traditionally grown by farmers on heavy black soils (udalfs) under rain fed conditions at altitudes of 1800-3000 m.a.s.l. and sometimes even above 3000 m (Perrino and Porceddu, 1990; Tesemma and Belay, 1991). Most tetraploid wheat varieties in Ethiopia are landraces which are often species mixtures (Eticha et al., 2006).
Ethiopian farmers traditionally grow several varietal mixtures in the same field that might have advantage to add variety to their diet and reduce the risk of pests and diseases or unusual environmental conditions (Bekele, 1984). Jain (2000) also stated that the folk often continue to grow traditional even less productive cultivars and wild relatives, and, therefore, preserve cultivars and genetic diversity.

In Ethiopia, cereals such as wheat and barley farmers cut the upper part of the 
Negash Gelata and Heinrich Grausgruber

culms and bundle it. The importance of this practice could be twofold: it may result in smaller amounts of weed seeds in the harvested seed and consequently in food and sowing seeds, and more importantly this helps to familiarize a farmer (or household) with the characteristics of the cultivars (Zeven, 2002). Farmers have built up knowledge of agriculture in general and of their crops and the methods of their cultivation and storage in particular and transferred this knowledge to next generations over millennia although they probably were often not well aware and did not write about their unique knowledge. However, old knowledge is lost because farmers adopt and adapt modern technologies (Zeven, 2000). Even today, it is evident that Ethiopian farmers are practicing traditional farming and their indigenous knowledge will continue and be passed to the coming generations unless some radical interventions are introduced. Ritualistic, symbolic and religious associations with bioresources are more deep-rooted in cultures, than the material uses of genetic resources (Jain, 2000). The exploitation or protection of bioresources, which is selective, influences the distribution, abundance and consequent availability, which in turn compels modification or substitution in plant or animal-man relationship. Thus, the analysis of the risk of loss of landraces, which represent wild populations, serves as the starting point for considering how the human factor may exercise its influence, and for the assertion that the human factor cannot be ignored (Tunstal et al., 2001).

Knowledge about the level and extent of diversity in crops such as wheat conserved onfarm is of great value for sustainable maintenance and utilization of genetic material
Sci. technol. arts Res. J., Jan-Mar 2013, 2(1): 01-09

(Kebebew et al., 2001; Teklu and Hammer, 2006; Tsegaye and Berg, 2007a,b). Studies on the assessment of loss of landraces and exploring the reasons of genetic erosion are done in the centres of diversity such as Ethiopia. The objectives of the study were: (1) to document wheat landraces that once were or still are grown in Ambo and Dandi districts of West Shewa, Ethiopia; and (2) to investigate the extent of genetic loss and its causes.

\section{MATERIALS AND METHODS}

\section{Study Area}

The study was carried out in Ambo and Dandi districts, West Shewa, Ethiopia (Figure 1). Three Peasant Associations (PAs) including Awaro, Gosu-Kora, and Ya'i-Chabo and two Peasant Associations including Warka-Warabo and BodaBosoka in Ambo and Dandi district respectively were used for the study from September to December 2007. From August to October 2008, similar study was carried out in four PAs namely Awaro and Gosu-Kora in Ambo District and Awash-Bole and Haro-Dule in Dandi District.

The study areas are characterized by plain to gentle or sharp slops. Some places are rugged, with high soil erosion problems, e.g. Ya'i-Chabo and Boda-Bosoka. Heavy black soils dominate in Awaro and Warka-Warabo, whereas clay sandy soils are dominant in Ya'i-Chabo. The two soil types differ especially in water holding capacity. Interestingly the adaptation of crops to these soil types also differs. Tef and wheat are widely adapted cereals to both soil types while barley is more adapted to sandy clay loam areas such as Ya'i-Chabo.

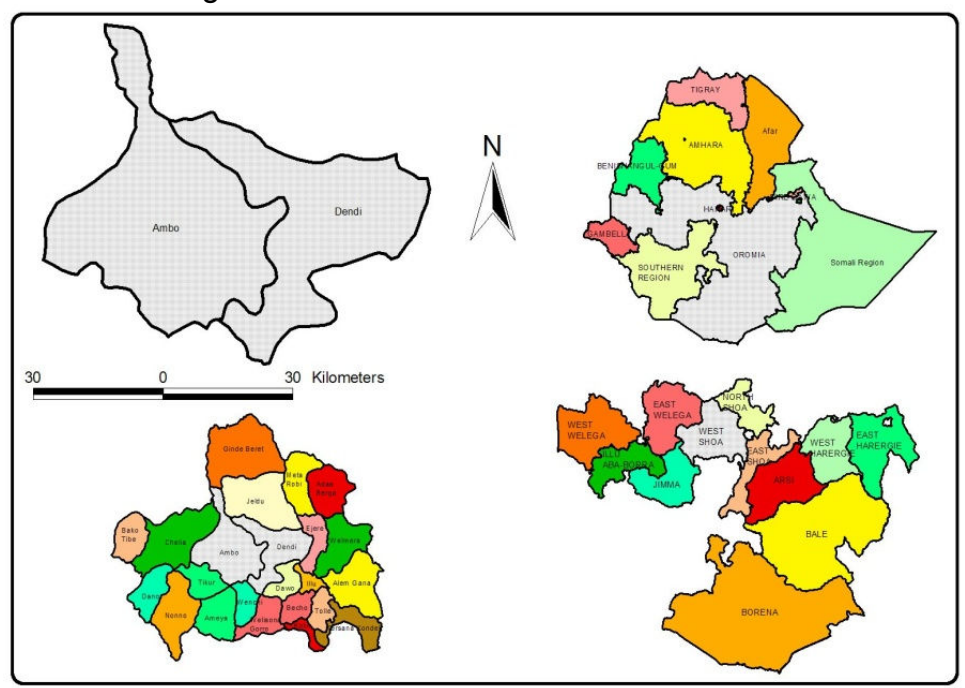

Figure 1: Map of Ethiopia (above right), Oromia (below right), West Shewa (below left), Ambo and Dandi districts (above left). 
Negash Gelata and Heinrich Grausgruber

\section{Methods of Data Collection}

\section{Group discussion}

Exploration of on-farm diversity of wheat landraces was carried out for the first time from September to December 2007. A questionnaire concerning production and conservation practices by the farmers was prepared. Three to five farmer groups per PA containing 5 to 12 individual farmers per group were formed. Development agents from the districts' agricultural offices assisted in organizing the farmers in groups. Selection of farmers was not exclusively random in order to include different age groups and gender. Discussions were made among different groups of farmers following the questionnaire. Equal opportunities were given to both gender groups during group discussion. After thorough discussion, consolidated ideas were noted.

\section{Household Survey}

Based on the information from 2007, a total of 90 households study in four PAs was carried out from August to September 2008. Each household was interviewed following the questionnaire prepared by the researcher. Development agents from the Agricultural Development Office assisted and organized the farmers for interview in both districts. Purposive selection of farmers was done by using age as the simple index to identify farmers with more experience. Households with different age groups and wealthy classes were included. Farmers compared the situation of wheat landraces cultivated 20 to 30 years ago with present situations. In most cases the age of the interviewed farmers' was more than 35 years.

\section{Statistical Analysis}

Descriptive statistics was used to describe the data of both study years. The data is more of qualitative than quantitative and mainly ideas from the group discussions were used to explain the problems. The present status of on-farm genetic diversity (or genetic erosion) of wheat landraces was assessed using the formula of Hammer et al. (1996) and it is given as:

$$
G E=100 \%-G I
$$

where $G E$ is genetic erosion and $G /$ is genetic integrity which is given as:

$$
G I=\frac{N_{2}}{N_{1}} \times 100 \%
$$

Sci. technol. arts Res. J., Jan-Mar 2013, 2(1): 01-09

where $N_{1}$ is the number of landrace varieties collected in previous times and $N_{2}$ is the number of presently collected landrace varieties. According to the same authors the number of years between $N_{1}$ and $N_{2}$ is usually 3 to 5 decades. In the present study, the number of all listed varieties once grown by the farmers is considered as $N_{1}$ (20 to 30 years ago) and the number of presently available landrace varieties represents $N_{2}$.

\section{RESULTS}

\section{On-Farm Status of Wheat Landraces}

A list of wheat landraces reported by the farmers is presented in Table 1. In total 20 landraces were listed by the farmers across the two districts. Sixteen and 13 landraces were listed from Ambo and Dandi, respectively, and some are common to both districts. Farmers of the study sites described the landraces based on morphological traits (e.g. maturity time, plant height, seed colour, glumes colour, awn length and colour, etc.), adaptation to biotic and abiotic stresses and end-uses. For instance, varieties such as Kamadi-Dima, Biraye, Badag/Shalu, and Lucha have purple coloured seeds. Badag/Shalu is a mixture of two varieties which are identified by the shape and size of ears. Badag has long and squared spikes whereas Shalu has short spikes. Wheat landraces also exhibit different seed size and shape. Kamadi-Dima, Biraye, Badag/Shalu, Gofari have large and elongated seeds, whereas Hayibo and Magal-Sala have large and semi-elongated seeds. Varieties such as Barsadadi, Kaffelli, and Lucha have small to intermediate and semi-elongated seeds. Farmers' varieties can also be grouped into different classes based on end uses, e.g. those mainly used for the preparation of different foods and snacks, and those used for the production of beverages.

Wheat landraces differ also in their reaction to diseases such as smut (Ustilago spp.) and rust (Puccinia spp.). Hayibo and Lucha are susceptible to rust, whereas Magal-Sala is susceptible to rust and smut, and Badag/Shalu is susceptible only to smut. Farmers expressed the problems in Afan Oromo (Oromo language) as "Sanyiin kun dhukkuba waagii ykn awaroo qabdii" which means that the respective variety has the problem of rust/smut disease. Hayibo and MagalSala are also susceptible to pre-harvest sprouting. 
Negash Gelata and Heinrich Grausgruber

Table 1: Wheat landraces of Ambo and Dandi districts, West Shewa, Ethiopia.

\begin{tabular}{lll}
\hline \multicolumn{2}{l}{ Wheat landraces } & \\
\hline Ambo & Dandi & $\begin{array}{l}\text { Common to Ambo } \\
\text { and Dandi }\end{array}$ \\
\hline Asnaka & Hayibo & Kamadi-Dima \\
Biranu & Magal-Sala & Biraye \\
Bataja / Butuji & Gofari & Badag / Shalu \\
Galane & Lucha & Kenya \\
Boroka & & Kaffelli \\
Fitale (Dalati) & & Barsadadi \\
Bushe & & Goli-Hinga'u \\
& & Bonde \\
& & Boyido \\
\hline
\end{tabular}

Farmers reported further that it is easier to remove hulls from Kaffelli than Barsadadi, indicating that both are only partially free threshing. Moreover, the landraces differ in their nutrient demand. For instance, Gofari is usually grown on fertile soil while Biraye and Badag/Shalu are grown on less fertile soils. Biraye, however, is susceptible to water logging. Kamadi-Dima and Lucha are grown on all ranges of soil types. Kaffelli, Barsadadi and Hayibo are grown only on well-drained soils. Bataja/Butuji can be grown on fertile heavy black soils (udalfs) since it is resistant to water logging. Galane can be grown on all types of soil, however, it gives higher yield on fertile soils. Additionally, it is resistant to water logging. Boroka is less competent than others when a field is infested with weeds. Moreover, it is susceptible to diseases and can easily be broken when touched by animals due to a very soft stem.

\section{Local Names of Landrace Varieties}

Local or vernacular names of wheat landraces have their own meanings (Table 2). For instance, Biranu is named after its bright seed colour. Butuji/Bataja is named after its short and strong stem, usually resistant to lodging. Hayibo means 'cheese' that refers to bread and other food products made from the white flour with good taste. Likewise, Magal-Sala means purple awns but white seeds. Galane is named after its tall plant height. The vernacular names are important within farming communities to distinguish a variety from the other. Vernacular names are simple and easily understood by farmers. They are also important to maintain the identity of a variety.
Sci. technol. arts Res. J., Jan-Mar 2013, 2(1): 01-09

Table 2: Examples of vernacular names of landraces and their meaning.

\begin{tabular}{|c|c|}
\hline $\begin{array}{l}\text { Local/ } \\
\text { Vernacular name }\end{array}$ & Meaning \\
\hline $\begin{array}{l}\text { Kamadi- } \\
\text { Dima }\end{array}$ & $\begin{array}{l}\text { 'Red/Purple wheat'; the name } \\
\text { refers to the seed colour }\end{array}$ \\
\hline Biraye & $\begin{array}{l}\text { refers to the extreme earliness; } \\
\text { it is adapted to well drained } \\
\text { soils }\end{array}$ \\
\hline Kenya & $\begin{array}{l}\text { Most probably this variety is } \\
\text { named after its original seed } \\
\text { source. }\end{array}$ \\
\hline Kaffelli & $\begin{array}{l}\text { The word Kaffelli is strange in } \\
\text { West Shewa communities. It is } \\
\text { assumed that this variety was } \\
\text { originally introduced from Italy }\end{array}$ \\
\hline Hayibo & $\begin{array}{l}\text { 'Cheese'; refers to the end use } \\
\text { quality }\end{array}$ \\
\hline Magal-Sala & 'Purple/black awned wheat' \\
\hline Gofari & 'Long awns' \\
\hline Boyido & 'Short awns' \\
\hline Lucha & 'Long awns' \\
\hline Asnaka & 'Better than others' \\
\hline Biranu & 'Bright/beautiful seed colour' \\
\hline Galane & Refers to its tall plant height \\
\hline Boroka & 'Soft stem' \\
\hline Goli-hinga'u & $\begin{array}{l}\text { 'No space to accommodate'; } \\
\text { refers to high grain yield }\end{array}$ \\
\hline Bataja/Butuji & $\begin{array}{l}\text { Refers to the short and strong } \\
\text { stem, and resistance to lodging }\end{array}$ \\
\hline Fitale (Dalati) & $\begin{array}{l}\text { 'White and attractive seed } \\
\text { colour' }\end{array}$ \\
\hline
\end{tabular}

\section{Genetic Erosion}

According to Brush (1999) genetic erosion may be defined as the global process under which landraces, previously adapted through thousands of years to different natural and manmade conditions are displaced by modern, mostly uniform and high-yielding varieties. In the present study, most tetraploid wheat landrace were replaced by improved wheat varieties. Genetic erosion was estimated for both districts systematically by exploring wheat landraces cultivated 20 to 30 years ago compared with the present situation. Genetic erosion was estimated for Ambo and Dandi districts as $75.0 \%$ and $61.5 \%$, respectively (Table 3 and Figure 2). From 20 wheat landraces reported for both districts not more than four to five landraces are grown at present time. Kamadi-Dima, Biraye and Bonde 
Negash Gelata and Heinrich Grausgruber

are still grown in both districts, while Gofari and Kenya are only grown in Dandi. The continuous cultivation of some landraces might be due to their unique end-use quality and wide adaptation to changing environments that is not obtained from other landraces or improved varieties. For instance, Kamadi-Dima is exclusively used for beverage and malt preparation (Figure 3). Some are adapted to low soil moisture because of their early maturity (e.g. Biraye) and are usually grown at the end of the rainy season on residual moisture. Other landraces with wide adaptation are more resistant/tolerant to pathogens and
Sci. technol. arts Res. J., Jan-Mar 2013, 2(1): 01-09

pests. Due to its end-use quality Kamadi-Dima is also more expensive at the market and, therefore, worth to be cultivated by the highland farmers. The old tetraploid landraces were replaced by improved bread wheat varieties at a faster rate in both districts. Genetic erosion is not only a threat to crop species but also to the sociocultural settings connected with the cultivation of this crop. Often both culture and beliefs support the conservation of the landraces, but once the landraces are lost the socio-cultural and religious values related to the cultivation of crops are no more existing either.

Table 3: Genetic erosion of tetraploid wheat landraces in Ambo and Dandi Districts.

\begin{tabular}{ccc}
\hline \multirow{2}{*}{ Number of cultivated landrace varieties } & \multicolumn{2}{c}{ District } \\
\cline { 2 - 3 } & Ambo & Dandi \\
\hline Number of landraces recalled by the farmers grown & 16 & 13 \\
before 2 to 3 decades & & \\
Number of landraces grown during 2007 and 2008 & 4 & 5 \\
Genetic integrity (\%) & 25.0 & 38.5 \\
Genetic erosion (\%) & 75.0 & 61.5 \\
\hline
\end{tabular}
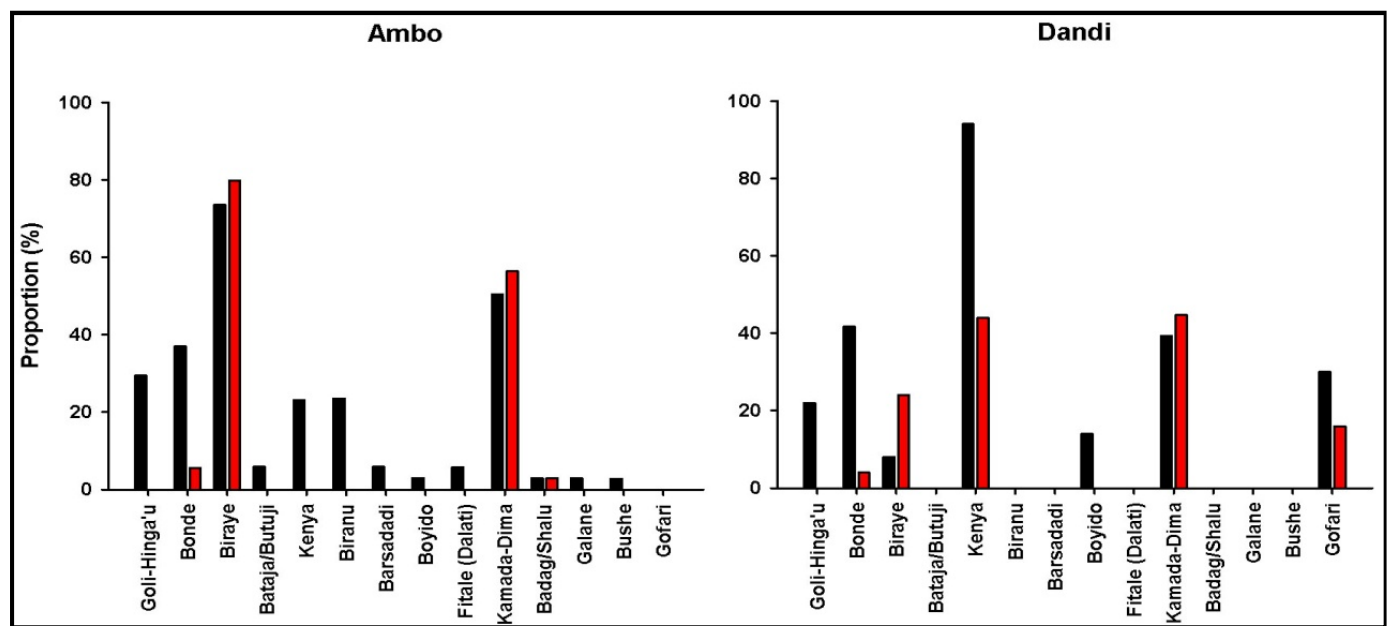

Figure 2: Proportion of households growing tetraploid wheat landraces before 2 to 3 decades (black bars) and in 2007 and 2008 (red bars) in Ambo and Dandi districts, West Shewa.
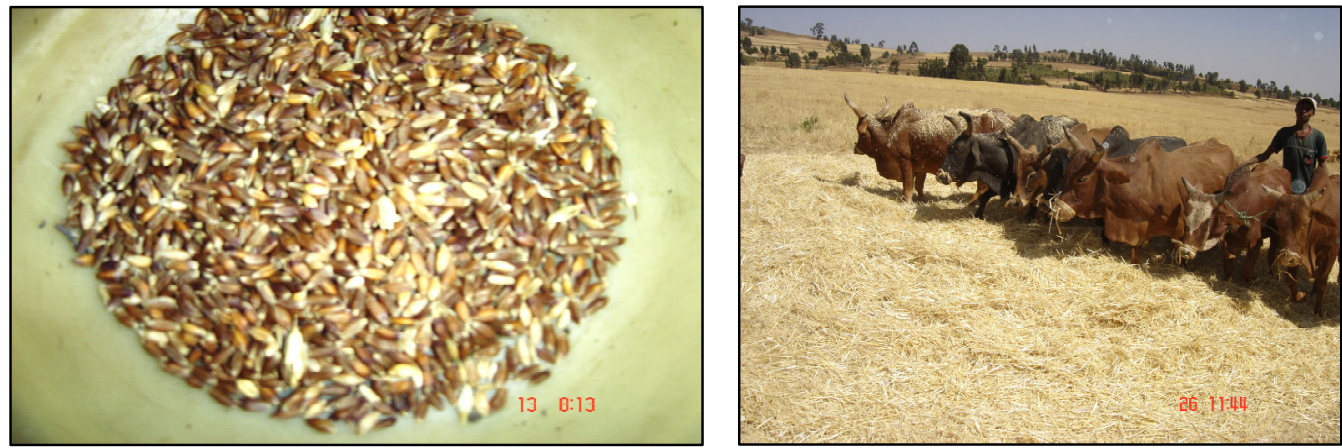

Figure 3: The popular purple seeded landrace variety ‘Kamadi Dima’ and traditional wheat threshing using oxen in West Shewa. 
Negash Gelata and Heinrich Grausgruber

\section{Causes for the Losses of Landraces}

Some causes of genetic erosion were identified (Figure 4, Tables 4 and 5). These included: (1) low yields of landraces and replacement by high yielding improved varieties; (2) climate change; rainy seasons are becoming shorter while old landraces are late maturing
Sci. technol. arts Res. J., Jan-Mar 2013, 2(1): 01-09

types; (3) poor soil fertility and land degradation contributed to the abandonment of some landraces which demanded fertile soils (this was clearly seen in Ya'i-Chabo PA); (4) market price and demand (e.g. Kamadi-Dima has good demand and high prices in the market).
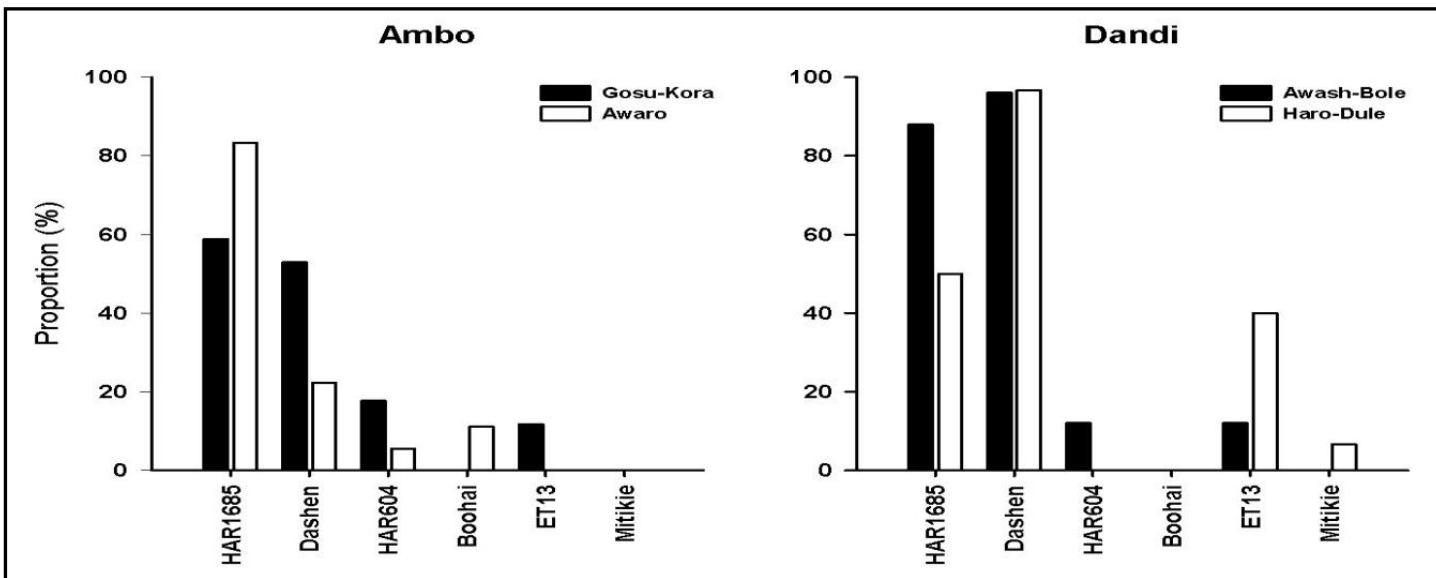

Figure 4: Proportion of households growing improved wheat varieties in Pas of Ambo and Dandi during 2007 and 2008. HAR1685, Dashen, HAR604, ET13 and Mitike are bread wheat varieties while Boohai is a durum wheat.

Table 4: Proportion of farmers citing different causes for changes in cropping system in Gosu-Kora and Awaro (Ambo).

\begin{tabular}{llll}
\hline \multicolumn{1}{c}{ Cause } & $\begin{array}{c}\text { Gosu-Kora } \\
(\mathbf{n = 1 7 )}\end{array}$ & $\begin{array}{c}\text { Awaro } \\
(\mathbf{n = 1 8 )}\end{array}$ & Average \\
\hline Market price and demand & 65 & 78 & 71.5 \\
Low productivity & 94 & 72 & 83 \\
Water logging conditions & 0 & 17 & 8.5 \\
Response to input & 0 & 11 & 5.5 \\
Food quality & 35 & 17 & 26 \\
Ease of processing & 0 & 6 & 3 \\
Maturity time & 71 & 6 & 38.5 \\
Availability of improved varieties & 6 & 0 & 3 \\
Climate change & 18 & 83 & 50.5 \\
\hline
\end{tabular}

Note: The percentage can add up to more than 100 since there are multiple answers per individual.

Table 5: Proportion of households citing different causes for loss of landraces in Awash-Bole and HaroDule (Dandi).

\begin{tabular}{lccc}
\hline Cause & $\begin{array}{c}\text { Awash-Bole } \\
(\mathbf{n = 2 5})\end{array}$ & $\begin{array}{c}\text { Haro-Dule } \\
(\mathbf{n = 3 0 )}\end{array}$ & Average \\
\hline Low productivity & 92 & 100 & 96.0 \\
Soil fertility / land degradation & 64 & 93 & 78.5 \\
Climate change & 56 & 57 & 56.5 \\
Lack of inputs & 32 & 20 & 26.0 \\
\hline
\end{tabular}

Note: The percentage can add up to more than 100 since there are multiple answers per individual 
Negash Gelata and Heinrich Grausgruber

\section{DISCUSSION}

In the present study, wheat landraces recorded from different study sites in Ambo and Dandi districts indicated that once there were rich diversities. In total 20 landraces which were cultivated within the last 20 to 30 years were reported for the two districts. Tsegaye and Berg (2007a) identified 26 different landraces from two districts, i.e. Akaki and Lume, of East Shewa. The authors indicated that in Lume an on-farm conservation program was established with the aim of re-introducing landraces which became extinct in recent time. In the present study farmers used morphological traits, disease resistances, adaptation to different soil types and end-use quality to differentiate landraces. Seed colour is such an important morphological trait for differentiation. Purple grain colour was originally only found in cultivated tetraploid wheat landraces of Ethiopia (Zeven, 1991). Belay et al. (1995) reported purple grains in all Ethiopian tetraploid wheats with the exception of $T$. dicoccum. Less frequent this trait appears in $T$. polonicum, whereas it is frequent in $T$. carthlicum and T. durum. In the present study, the farmers reported that two landraces, i.e. Barsadadi and Kaffelli, are hulled and/or partially free-threshing. This gives indication that there might be some gene introgression from T. dicoccum. According to Feldman (1976) T. dicoccum was the first tetraploid wheat introduced to Ethiopia. Today, it is not widely cultivated except in some marginal areas (D'Andrea and Haile, 2002).

The landraces exhibited different nutrient demands. Some are adapted to less fertile and poorly drained soils, whereas others need fertile and well drained soils. Moreover, the landraces exhibited differential responses to diseases and pests (e.g. susceptible to resistant types). In wheat breeding history Ethiopian tetraploid wheat landraces were often used as sources of earliness, disease and pest resistance, nutritional quality, resistance to drought and other stresses, adaptation to low soil fertility and other characteristics useful in low-input agriculture (Worede, 1997).

Some of the landraces are common to both districts. Ambo and Dandi are neighbouring districts. People living there share common sociocultural settings and believes. For example Kamadi-Dima is grown in both districts because of its unique end-use, i.e. preparation of malt and beverages. Therefore, this landrace reaches high prices at the market. Transfer of landraces from one place to another is done by (1) gifts among relatives, (2) purchase from market, (3) by
Sci. technol. arts Res. J., Jan-Mar 2013, 2(1): 01-09

migration of people in search for fertile land, free land or other social aspects. In Ethiopia it is common to find households moving from one place to another in search for fertile farming land, relatives etc. Landraces are often more stable and adapted to wider areas compared to improved varieties. Tesemma et al. (1993) stated that Ethiopian wheat landraces are usually mixtures of different agro-types having wider gene pools within one population that can buffer the change of climatic and edaphic factors. Eticha et al. (2006) also reported mixtures of five tetraploid wheat landraces and hexaploid wheat in varying proportions in one population of germplams collected from Bale and Welo regions. The species mixtures/agro-types might have an advantage for the farmers when grown in the same field: to add variety to the diet and, on the other hand, to carry diverse genes for disease and pest resistances and adaptability to changing climatic factors (Bekele, 1984).

In the present study, most of the tetraploid wheat landraces were either totally abandoned, or marginalized within the last decades. The most serious cause of genetic erosion is the wide adoption of improved common wheat varieties by the farmers, although there are also other factors like expansion of other crops like tef, low productivity of landraces, climate change, long maturity time of landraces, diseases, and reduced land size, etc. Already Baur (1914) warned about genetic erosion but it was ignored for about 2 decades until the American 'plant explorers' Harlan and Martini (1936) were credited with first recognizing the problem (Hammer \& Laghetti, 2005). Worede (1997) reported the seriousness of genetic erosion of wheat landraces and barley in Ethiopia that might be caused by different factors such as drought, famine, expansion of other crops and improved seeds (improved hexaploid wheat) etc. Similar losses of tetraploid wheat landraces as in the present study were recorded by other researchers (Tsegaye, 1997; Teklu and Hammer 2006; Tsegaye and Berg 2007a) in different parts of Ethiopia, indicating that this species are in danger. Genetic erosion within and between crop species is a worldwide problem and it is mainly related to modern agriculture, whereby uniform and high yielding varieties are grown on large scale and replaced the landraces. In addition, climate change and drought, fire, war, etc. are some other causes of genetic erosion. Shewayrga et al. (2008) reported genetic erosion in sorghum for north-eastern Ethiopia caused by declining soil fertility, frequent drought and unreliable rainfall, and increased pest infestations. The authors reported that landraces 
Negash Gelata and Heinrich Grausgruber

that are less preferred in terms of agronomic value and end-use, introductions have become increasingly important while late maturing types were found to be vulnerable to genetic erosion. Mekbib (2008a) reported genetic erosion in sorghum for eastern Ethiopia caused by reduced benefits from the varieties, drought, khat expansion, reduced land size and introduction of other food crops. In the present investigation drought, fire, and war are not factors for genetic erosion. Reduced soil fertility, reduced land size and expansion of improved common wheat varieties are the major causes. However, other researchers (Teklu and Hammer, 2006; Tsegaye and Berg, 2007a) reported drought as one factor of genetic erosion in tetraploid wheat landraces especially in eastern part of Ethiopia.

Several scientific papers reviewing or investigating genetic erosion in crop species in different countries are available. Oliveira and Martins (2002) estimated genetic erosion of ipecac (Psychotria ipecacuanha), a medicinal plant in Brazil. Hammer et al. (1996) studied genetic erosion in cereals, vegetables, pulses and other crops in Albania and South Italy. In developing countries like Ethiopia the situation is worse since the ex-situ collections are not exhaustive. Moreover, some of the accessions conserved ex-situ lack sufficient data (Teklu and Hammer, 2006). Moreover, there are indications in the Ethiopian Gene Bank that some durum wheat landraces have lost vigour when planted in the field; and seeds for some accessions in exsitu were exhausted because of requests by different institutions for research and breeding (Teklu and Hammer, 2006). Fast and huge conservation measures are necessary to protect the landraces before they are lost forever. Hammer and Laghetti (2005) calculated a genetic erosion rate for cereal, pulses and vegetables in Italy. It was high (13.2\%) in early times, from 1920 to 1950 , and it was low (4\%) in late times, from 1950 to 1980. After the 1950s, people became aware of losses of agro-biodiversity and they tried to protect the landraces. In the late 1920s N.I. Vavilov explored Ethiopia and he was amazed by the high genetic diversity in wheat landraces particularly in durum wheat and barley. This is an indication how loss of agro-biodiversity is going fast unless strong attention is given to protect these landraces from vanishing forever.

\section{CONCLUSIONS}

Dandi and Ambo districts are among the major tetraploid wheat cultivation zones of western Ethiopia. Generally, the farmers in both districts recalled 20 wheat landraces. However, presently
Sci. technol. arts Res. J., Jan-Mar 2013, 2(1): 01-09

4 to 5 landraces are cultivated. Therefore, genetic erosion in tetraploid wheat reached greater than $60 \%$. This calls for due attention of every stakeholder in order to stop biodiversity degradation. The loss of landraces was accounted to different causes. These included the expansion of improved bread wheat varieties, low soil fertility and poor yield of the landraces, and short rainy season period since most landraces are long maturing types. Among the available varieties, kamadi-Dima, is predominantly grown in both districts due to its high brewing quality and higher price in the market.

\section{ACKNOWLEDGEMENT}

The authors are very grateful to the farmers of the Dandi and Ambo Districts for the valuable information and experience they shared. We also thank to the Dandi and Ambo Agricultural Offices for they have shown cooperation in giving secondary information. The study was financially supported by Austrian Cooperation in Higher Education and Research.

\section{REFERENCES}

Baur, E. (1914). Die Bedeutung der primitiven Kulturrassen und der wilden Verwandten unserer Kulturpflanzen für die Pflanzenzüchtung. Jahrbuch DLG, Februartagung Berlin (Saatzuchtabteilung), pp 104-109.

Bechere, E., Kebede, H. and Belay, G. (2000). Durum wheat in Ethiopia: an old crop in an ancient land. Institute of Biodiversity Conservation and Research, Addis Ababa.

Bekele, E. (1984). Analysis of regional patterns of phenotypic diversity in the Ethiopian tetraploid and hexaploid wheats. Hereditas, 100, 119-134.

Belay, G., Tesemma, T., Bechere, E. and Mitiku, D. (1995). Natural and human selection for purplegrain tetraploid wheats in Ethiopian highlands. Genetic Resources and Crop Evolutionl, 42, 387391.

Brush, S. (1999). Genetic erosion of crop populations in centres of diversity: a review. Proceedings of The FAO Technical Meeting on Methodology of The World Information and Early Warning System on Plant Genetic Resources, 21-23 June, Prague, pp 34-44.

D'Andrea, C.A. and Haile, M. (2002). Traditional emmer processing in Highland Ethiopia. Journal of Ethnobilogy, 22, 179-217.

Eticha, F., Belay, G. and Bekele, E. (2006). Species diversity in wheat landrace populations from two regions of Ethiopia. Genetic Resources and Crop Evolutionl, 53, 387-393. 


\section{Negash Gelata and Heinrich Grausgruber}

Feldman, M. (1976). Wheats. In: N.W. Simmonds (Ed.), Evolution of Crop Plants (pp. 120-126). London, Longman Scientific \& Technical.

Hammer, K., Knüpffer, H., Xhuveli, L. and Perrino, P. (1996). Estimating genetic erosion in landraces two case studies. Genetic Resources and Crop Evolutionl, 43, 329-336.

Hammer, K. and Laghetti, G. (2005). Genetic erosion examples from Italy. Genetic Resources and Crop Evolutionl, 52, 629-634.

Harlan, H.R. and Martini, M.L. (1936). Problems and Results of Barley Breeding. USDA Yearbook of Agriculture. U.S. Government Printing Office, Washington, D.C, pp. 303-346.

Jain, S.K. (2000). Human aspects of plant biodiversity. Economic Botony, 54, 459-470.

Kebebew, F., Tsehaye, Y. and McNeilly, T. (2001). Diversity of durum wheat (Triticum durum Desf.) at the in situ conservation sites in North Shewa and Bale. Ethiopian Journal of Agricultural Science, 136, 383-392.

Mekbib, F. (2008a). Genetic erosion of sorghum (Sorghum bicolour (L.) Moench) in the center of diversity. Genetic Resources and Crop Evolutionl, $55,351-364$.

Oliveira, L.O. and Martins, E.R. (2002) A quantitative assessment of genetic erosion in ipecac (Psychotria ipecacuanha). Genetic Resources and Crop Evolutionl, 49, 607-617.

Perrino, P. and Porceddu, E. (1990). Wheat genetic resources in Ethiopia and the Mediterranean region. In: J.P. Srivastava and A.B. Damania (Eds.) Wheat Genetic Resources: Meeting Diverse Needs (pp. 161-178). Chichester, John Wiley \& Sons.

Shewayrga, H., Jordan, D.R. and Godwin, I.D. (2008). Genetic erosion and changes in distribution of sorghum (Sorghum bicolor (L.) Moench) landraces in north-eastern Ethiopia. Plant Genetic Resources, $6,1-10$.

Teklu, Y. and Hammer, K. (2006). Farmers' perception and genetic erosion of tetraploid wheat landraces in Ethiopia. Genetic Resources and Crop Evolutionl, 43, 1099-1113.
Sci. technol. arts Res. J., Jan-Mar 2013, 2(1): 01-09

Tesemma, T. and Belay, G. (1991). Aspects of Ethiopian tetraploid wheats with emphasis on durum wheat genetics and breeding research. In: H. Gebre-Mariam, D.J. Tanner, and M. Huluka (Eds.), Wheat Research in Ethiopia: A Historical Perspective (pp. 47-71). Addis Ababa, IAR/CIMMYT.

Tesemma, T., Becker, H.C., Belay, G., Mitiku, D. Bechere, E. and Tsegaye, S. (1993) Performance of Ethiopian tetraploid wheat landraces at their collection sites. Euphytica, 71, 221-230.

Tsegaye, B. (1997). The significance of biodiversity for sustaining agricultural production and role of women in the traditional sector: the Ethiopian experience. Agriculture, Ecosystems and Environment, 62, 215-227.

Tsegaye, B. and Berg, T. (2007a) Genetic erosion of Ethiopian tetraploid wheat landraces in Eastern Shewa, Central Ethiopia. Genetic Resources and Crop Evolutionl, 54, 715-726.

Tsegaye, B. and Berg, T. (2007b). Utilization of durum wheat landraces in East Shewa, central Ethiopia: Are home uses an incentive for on-farm conservation? Agric Human Values, 24, 219-230.

Tunstal, V., Teshome, A. and Torreance, J.K. (2001). Distribution, abundance and risk of loss of sorghum landraces in four communities in North Shewa and South Welo, Ethiopia. Genetic Resources and Crop Evolutionl, 48, 131-142.

Worede, M. (1997). Ethiopian in situ conservation. In: N. Maxted, B.V. Ford-Lloyd, and J.G. Hawkes (Eds.), Plant Genetic Conservation: The In situ Approach( pp. 290-301). London, Chapman \& Hall.

Zeven, A.C. (1991). Wheats with purple and blue grain: a review. Euphytica 56, 243-258.

Zeven, A.C. (2000) Traditional maintenance breeding of landraces: 1. Data by crop. Euphytica, 116, 6585.

Zeven, A.C. (2002). Traditional maintenance breeding of landraces: 2. Practical and theoretical considerations on maintenance of variation of landraces by farmers and gardeners. Euphytica, $123,147-158$ 